\title{
Ordu’da Körüklü Çizme ve Türkay Yavaş Ustanın Tekniği
}

\author{
M. Akif KORKMAZ*
}

\section{Öz}

Usta çırak eğitimi ve el sanatı yoluyla aktarılan meslekler, geleneksel mesleklerdir. Bu bağlamda ele alındığında tamamen alın teri ve göz nuruna dayanan beceri isteyen körüklü çizmecilik, geleneksel meslekler arasında yer almaktadır. Bu makalede Ordu'da ve Karadeniz bölgesinde çizmecilik mesleği yapanların kalmamasının ardından Kuşadası'na yapılan uzun ve yorucu bir yolculuk, orada mesleği öğrenmek için verilen çabalar, bunun sonucunda Ordu'da körüklü çizme giyme ve yapma geleneğinin yaşatılmasına vesile olan Türkay Yavaş Usta ve onun körüklü çizme yapımı anlatılmaktadır. Körüklü çizme Türkay Ustanın çabalarıyla günümüz yayla şenliklerinde, Mayıs Yedisi, Hıdırellez gibi mahallî ve mevsimsel törenlerde, at yarışlarında, düğünlerde canlandırılan bir gelenek olarak devam etmektedir. Bugün Ordu ili ve yakın bölgelerde at yetiştiricileri ve at binicileri tarafından giyilen akordeon körüklü çizme, yayla festivallerinde yerel kıyafetlerle birlikte giyilmiştir. Bu giysi aksesuarları ve çizme, daha önce geniş arazileri olan ağa olarak bilinen zengin insanların asaletinin simgesidir. Çalışmada Ordu'da Körüklü Çizme geleneğinin geçmişini ve bugününü ele alarak geleneksel mesleğin yaşatılması hususunda çabalar sarf eden bir ustanın hikâyesini, körüklü çizmenin nasıl yapıldığını ve üretim boyutunu hayata uyum bağlamında gelenek ve değişim ilişkilerine göre ele alıp incelenmiştir.

Anahtar Kelimeler: Körüklü çizme, Türkay Yavaş, kaybolmaya yüz tutmuş meslekler.

* Dr. Öğr. Üyesi, Giresun Üniversitesi, Fen Edebiyat Fakültesi, TDE Bölümü / Türk Halkbilimi, Giresun, Türkiye. Elmek: korkmazmakif@hotmail.com https://orcid.org/0000-0002-5280-8250 


\title{
Accordion Boots in Ordu and the Technique of the Shoe Master Türkay Yavaş
}

\begin{abstract}
Occupations that are transferred from one generation to the next in a master-apprentice relationship are called traditional occupations. The most important point in determining traditional occupations is whether the profession is based on handicrafts. In this regard, making accordion boots, which require a specialized knowledge and great effort, is among traditional occupations. In this article, a long and tiring journey to Kuşadası due to the absence of those who used to do this profession in Ordu and the Black Sea Region, the efforts made to learn the profession there, and Türkay Usta (master), who had a leading role in keeping the tradition of accordion boots in Ordu, and how he makes these boots are explained. With the efforts of Türkay Usta, the tradition of wearing accordion boots continue to be followed in highland festivals, local and seasonal ceremonies such as the Seventh of May festival, Hidirellez, horse races and weddings. Since the construction phase of accordion boots is very difficult and there are difficulties in finding and raising apprentices as it does not bring much income, Türkay Usta, who is the only master, or craftsman, in Ordu and even in the Black Sea, needs to be supported and evaluated in vocational training and it needs to be ensured that he takes part in traditional product sales places. Accordion bellows boots worn by horse breeders and horse riders are worn together with local clothes at highland festivals. These garment accessories and boots are the symbol of the nobility of wealthy people, formerly known as the network, with large lands. In this study, the story of a craftsman who has been trying hard to keep the tradition of accordion boot making and wearing alive and how accordion boots are made are examined considering and discussing the past and present of the tradition.
\end{abstract}

Keywords: Accordion boots, Turkay Yavaş, vanishing professions. 


\section{Extended Summary}

Occupations that are transferred from one generation to the next in a master-apprentice relationship are called traditional occupations. The most important point in determining traditional occupations is whether the profession is based on handicrafts. In this regard, making accordion boots, which require a specialized knowledge and great effort, is among traditional occupations.

The tradition of making and wearing accordion boots hardly continues in Ordu today. Türkay Yavaş, an accordion boot master, was born in 1962 in Uzunmahmut Village of Ulubey, Ordu. He entered the profession of shoemaking at an early age. He started to work with Avni Yeşiltepe, who was one of the famous masters of that period and making women's boots. There, he learned the subtleties of the profession and received advice from his master, the master of Greece, Mehmet Yeşiltepe.

After seven years of apprenticeship, followed by being a journeyman and craftsman, he went to Istanbul and then he returned to Ordu and opened a shop in 1985 in front of Orta Mosque. When Bekir Usta, a "jodhpur pants" master next door asked:

- "Everybody comes and asks me for accordion boots, why don't you make them?" he curiosity raised on accordion boots.

The master, who went into a long search period to learn how to make accordion boots, went to Kuşadası, a district of Aydın province, and got help from an accordion boots master called Mustafa Karpuzcu, the son of Mehmet Karpuzcu. He made his first boots in nine days and returned to Ordu with his first accordion boots and a pair of lasts called "kama".

When he came back to Ordu, he started making accordion boots in his own shop in Yeni Mahalle. He states that after his first samples in Kuşadası and Ordu, he made a masterful boot that had a unique production technique and model in about fifteen days. He always keeps the first lasts he brought from Kuşadası and the first accordion boots he made in sight in the shop. 
In 2015, Türkay Usta was selected as the "Akhi” (brother) of the year by the Ministry of Customs and Trade. During the celebrations of the 28th Akhism Week, the Governor of Ordu, the Mayor and the other officials took a city tour wearing accordion boots and got place in the local and national press. He is married and has two children.

The purpose of using accordion folds in accordion boots is both to make people look stylish and to let the air in the shoe. There are three or seven accordion folds in one accordion boot and these boots are also called diamond or accordion boots.

Boots without an accordion fold are called "aceska". Since these boots do not let the air in, it is difficult to wear them and they make feet sweaty. As it is difficult to wear them, there is a saying that goes "One who wears aceska sweats." In the Ottoman period, officers and Miralay Osman Agha (landlord) from Giresun wore these boots.

Today, accordion boots, worn in Ordu region by horse breeders and horseback riders, are mostly worn at the plateau festivals together with local clothes. Boots with accordions were a symbol of nobility for the wealthy people formerly known as agha who had large areas of lands. They used to go to the bazaar and rode horses with them. "Squeaky" boots would also make the agha look stylish while shopping.

Today, especially in the festivals held during the Akhism Week, the notable people of the region such as the governor, the mayor, the president of the chamber of artisans etc wear Accordion Boots together with an "octagonal flat cap" and "the British 'jodhpur' pants" walk among the people.

In this article, a long and tiring journey to Kuşadası due to the absence of those who used to do this profession in Ordu and the Black Sea Region, the efforts made to learn the profession there, and Türkay Usta, who had a leading role in keeping the tradition of accordion boots in Ordu, and how he makes these boots are explained. With the efforts of Türkay Usta, the tradition of wearing accordion boots continue to be followed in highland festivals, local and seasonal ceremonies such as the Seventh of May festival, Hidirellez, horse races and weddings. Since the construction phase of accordion boots is very difficult and there are difficulties in finding and raising apprentices as it does not bring much 
income, Türkay Usta, who is the only master, or craftsman, in Ordu and even in the Black Sea, needs to be supported and evaluated in vocational training and it needs to be ensured that he takes part in traditional product sales places. In this study, the story of a craftsman who has been trying hard to keep the tradition of accordion boot making and wearing alive and how accordion boots are made are examined considering and discussing the past and present of the tradition. 



\section{Giriş}

İstekler ve ihtiyaçlar üretimin en temel öğesidir. Kültürel değişimler istek ve ihtiyaçları da değiştirmektedir. Bir zamanlar basit ayakkabılar temel ihtiyaçlara cevap verirken, ortaya çıan formlar, zamanla estetize edilmiş körüklü çizme ortaya çıkmıştır. Bu yeni ürün artık varlık ve gösteriş sembolü olmuş ve hatta makam ve mevki göstergesi hâlini almıştır. Aynı zamanda bu ihtiyaçlar, yani geleneğin işlevsel değişimi toplumda yeni sanat ve zanaatların oluşmasına sanatkâr ve zanaatkârların yetişmesine neden olmuştur. Bu bağlamda maddi her kültür, birtakım sanat ve zanaatları yok ederken yenilerini de oluşturmuştur.

Batıda sanayi devrimiyle ortaya çıkan sermaye ve buna bağlı yeni üretim, küçük meslek erbabı ustalarını yenmiş; onların yerini makineler, küçük dükkânların yerini de büyük fabrikalar almıştır. Ustaların tekniğini ve kültürel alın terini yaşatmak için UNESCO tarafından çalışmalar yapılmaktadır. UNESCO Somut Olmayan Kültürel Mirasın Korunması Sözleşmesi'ni yayınlayarak bütün dünyadaki piyasaya direnebilmiş geleneksel meslekleri koruma altına almaya çalışmaktadır.

Gelenek veya eski zamanlardan beri devam eden bireysel becerilerle en başından sonuna kadar bir ürüne can veren sanat ile onun meslek olması iç içe bir yapıdır. Genel anlamda meslek kavramını ve olgusunu "Meslek Rehberliği ve Danışmanlığına Giriş" eserinde Y. Kuzgun şöyle tanımlamıştır: "İnsanlara yararlı mal ya da hizmet üretmek ve karşılığında para kazanmak için yapılan, belli bir eğitimle kazanılan sistemli bilgi ve becerilere dayal, kuralları toplumca belirlenmiş etkinlikler bütünüdür” (Kuzgun 2003: 15). Bunun karşısında geleneksel kültürel üretim yapan insanlar, bireysel ve çevresel sınırlı şartlarda kendi bedenlerine dayanarak var olmaktadırlar. Geleneksel meslekte tüm yapılar, her ne sebeple olursa olsun bireyin özgür seçimine bağlı şartlarda usta - çırak ilişkisiyle nesilden nesle aktarılarak gelir. Mesleğin seçimi ile yaşama biçimi tam anlamda uyum içinde başlar ve devam eder. Yoksa o meslek bu ustayı yetiştiremez, ustanın var oluşu yani hayat formu veya yaşama biçimi mesleğiyle uyumlu olmaktan geçer. 
Sosyal grupların yaşama biçimleri kültür adıyla ifade edilir ve o kültür insanın insanla ve toplumla olan bağı ve örüntülerinden oluşurlar. Meslek ve meslek erbabı olan esnaflar, insanlar arası bağlarda merkezi bir öneme sahip olmasına rağmen toplum bilimlerinde ve bilhassa halkbilimde pek çok yerde gözden kaçmıştır. Sedat Veyis Örnek (1995: 121) bu sosyal düzeni örf, adet, teamül, anane, gelenek, görenek, töre ve moda olarak sekiz formda sınıflandırmıştır. Görüldüğü üzere toplumsal yapıya beden olan örüntüler soyutlamalar üzerinden açıklanmaya çalışılmaktadır. Oysa bu sosyal normların içindeki müşahhas noktalardan biri meslekler ve meslek erbabı eksiktir. En eski anlatı olan Oğuz Kağan Destanı (Ergin 1970) ile Dede Korkut Kitabı (Ergin 1958) içindeki motiflerde marangoz, derici, demirci, silah ustası, otacı, çalg1 yapımcısı, ormanc1 ve keresteci, meyveci, araba-kağnı ustası, çilingir, terzi vb. meslek icra ediciler yani ustalık gösterenler öne çıkarılmıştır. Buna göre Türklerin hayatında, tarih sahnelerinde görünmelerinden bu yana, varlıklarını, bütünlüklerini ve farklılıklarını koruyan, ihtiyaçlarını her anlamda karşılayan sosyal ve siyasi düzenleri içinde birçok meslek görülmüştür. Çalışmayı konusu gereği çok fazla genişletmeden tarih içinden akıp gelmiş bir süreklilik vasfına sahip bu düzenlerin hepsine, kısaca gelenek adı verilebilir. Meslekler de bu geleneğin bir parçasıdır (Yıldırım 1998: 81-82). Metin Ekici geleneği, "eskiden beri devam edip gelen, gayri resmi yol ve yöntemlerle kazanılan ve kuşaktan kuşağa aktarılan ve zamanın ihtiyaçlarına göre her kuşakta belli ölçüde bireysel yaratıcılığa ve değişmeye ve de gelişmeye izin veren bilgi, hareket ve materyal ürünleri üretme ve kullanma tarzı" (Ekici 2007: 20) şeklinde tanımlamaktadır. Buna göre elde yapımına devam edegelmiş yemenicilik, ayakkabıcılık ve körüklü çizmeciliğin günümüzün bazı meslekleri arasında eski geleneğin bir parçası olduğu açıkça görülmektedir.

Geleneksel mesleklerin tespit edilmesinde dikkat edilecek en önemli husus söz konusu mesleğin el sanatına dayanıyor olmasıdır. El sanatı ürünü bir mesleğin eskiliği ve geleneksel üretim ilişkileri içerisinde olması, o mesleğe geleneksel bir kimlik kazandıracaktır. Bu durumda sanayi devrimi öncesinden gelen el becerisi ve alın terine dayanan meslekler, geleneksel meslekler grubuna girmektedir (Yolcu 2014: 2). Bu bağlamda ele alındığında tamamen alın teri ve göz nuruna dayanan bir ustalık isteyen körüklü çizmecilik geleneksel meslekler arasında yer almaktadır. 
Dünyada nâdir örnekleri ele geçmiş olanların, günümüze kadar gelebilmiş ayakkabıc1lık mesleğin ürünü ilk olarak sandalet şeklinde sicak ülkelerde ortaya çıkmıştır. Bu tip ayakkabılara Mısır mezarlarında rastlanmaktadır. Orta Doğu'da ayağın sıcak kumlardan korunması için yüksek topuklar yapılmıştır. Avrupa'da 1115. yy.larda sivri burunlu ayakkabilar modayken daha sonra 16-17. yy.larda topuklu ayakkabılar kullanılmaya başlamış ve topuklar kırmızıya boyanmıştır. 17. yy.da uzun topuklu çizmeler yaygınlaşmış, moda olan dantelli çorapların görünmesi için çizmelerin üst kenarları aşağı kıvrılmıştır (Esnaf ve Sanatkârlar... 2017: 21).

Eski Türk kültüründe ise ayakkabılar tahtadan, keçeden ve deriden olmak üzere üç şekilde yapılmaktaydı (Baykara 2001: 94). Orta Asya'da Türklerin yerleşik hayata geçtiği dönemden itibaren ortaya çıkan ve kesin şeklini bozkır kültüründen alan kıyafet tarzı ve buna bağlı olan çizmeler, Ön-Türkler, Hunlar, Göktürkler, Uygurlar ve diğer Türk topluluklarında yaygın biçimde kullanılmıştır (Çoruhlu 2003: 160). Özellikle askerî kıyafetler, sıcak ve soğukta ayrı ayrı giyilen pelerinler, ayaklara giyilen çizmeler ve başa giyilen börkler Türklerde çok yaygınd1. Börk ve çizmenin şekline göre o kişinin makam ve mevkii belli olurdu (Kafesoğlu 2016: 306). Selçuklu ve Osmanlılar döneminde ordunun, yönetici s1nıfın ve halkın giyeceği ayakkabılar tasarlanmış ve ayakkabı çeşitliliği artmıştır. Ayrıca Osmanlılarda ayakkabı, giyen kişinin toplumsal konumuna ve mesleğine göre farkl1l1klar göstermekteydi (Komisyon 2017: 21). Eski Türklerde, Osmanlı ve Selçuklu Dönemlerinde börk ve çizmenin ifade ettiği anlamlar bugünkü yeni işlevselliklere bağlı bir gelenek halinde bugün Ordu'da körüklü çizmeyle devam etmektedir. Çizme ile beraber aba zıpka, kasket, İngiliz kilot pantolon, yelek, gömlek ve çorap gibi kıyafet unsurları Doğu Karadeniz halk dansları gösterilerinde kullanılan temel öğelerdir. Bu kıyafetlerin bütününden yahut da birkaçından oluşan düğünler, çarşı pazar yerlerinde giyinip kuşanmalı kullanımlar neredeyse yok olmaya yüz tutmuştur. Bu tip geleneksel kıyafet meraklıları daha çok atadan dededen varlıklı ve geleneği kendi atalarından beri taşıyan erkeklerdir.

\section{Ordu'da Körüklü Çizme Ustası Türkay Yavaş}

Körüklü çizme ustası Türkay Yavaş 1962 yılında Ordu'nun Ulubey ilçesinin Uzunmahmut köyünde doğmuştur. Dokuz kardeşten biri olan Türkay Yavaş, 
çocukluk ve gençlik yıllarının yokluk içinde geçtiğini dile getirmektedir. İlkokulu bitirdikten sonra 1974 yılında, kendi ifadesiyle Ecevit affının yapıldığı yılda, eski itfaiyenin yanında bulunan Meram Kundura'da o yıllarda 35 yaşında olan ustası Avni Yeşiltepe'nin yanında bayan çizmesi yapmayla işe başlamıştır. Burada mesleğin inceliklerini öğrenmiş, ustasının ustası (Avni Yeşiltepe'nin Ustas1) Yunanistan mübâdili olan 1923 Yılında Selanik’ten Ordu'ya göçmüş Mehmet Yeşiltepe'den mesleğiyle ilgili tavsiyeler almıştır.

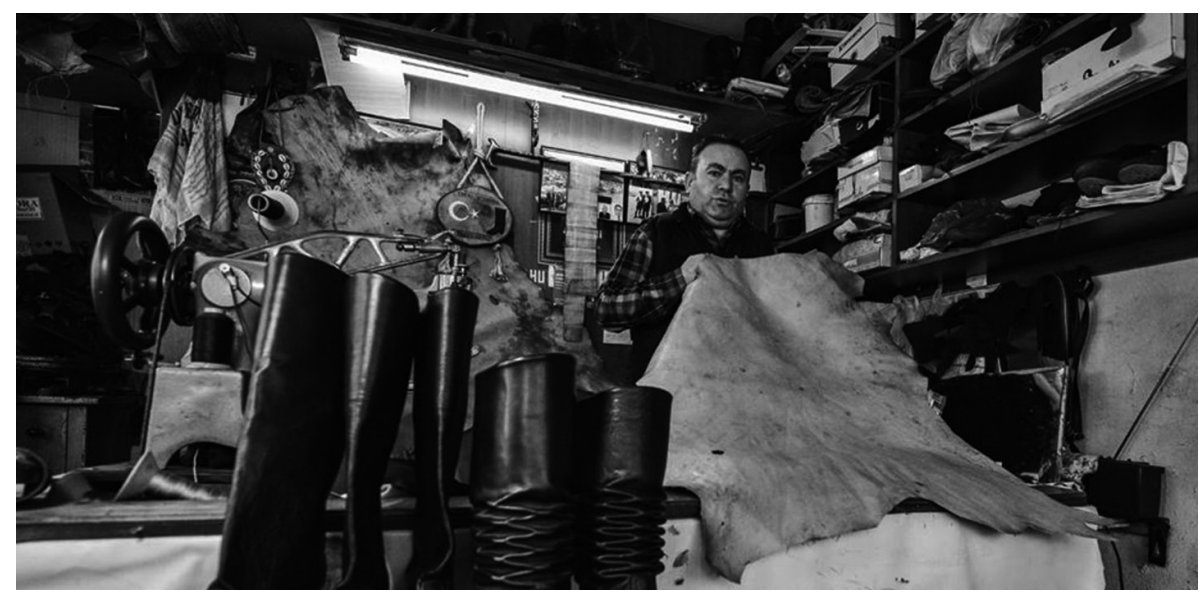

Foto 1. Çizme Ustası Turgay Yavaş tezgâhın başında çizmelerini sergiliyor, elinde çizmenin temel maddesi tabaklanmış sığır derisi var (Ahmet Kılıç arşivi, 2019).

O yıllarda bir çift ayakkabıyı sabahtan öğleye kadar ancak yapabildiklerini (pistirizma yaptıklarını) söyleyen Türkay Usta, aynı zamanda o dönemde zanaatın kıymetinin ve ekmeğin tadının olduğunu belirtmektedir. Yedi yıllık çıraklık, kalfalık ve ustalık döneminin ardından İstanbul'a gitmiş, 1982-1985 yılları arasında Beyoğlu'nun Avanoz Sokağında çalışmış, ayakkabı tamiriyle hayatını sürdürmüştür. Sonra tekrar Orduya gelen usta 1985 'te Orta Cami’nin önüne dükkân açmış, 1992'de dükkânını Yeni Mahalle'ye Kahraman Sagra Caddesi’nde tek kat1 küçük bir binanın zemin katına taşımıştır. Ustanın dükkânı Ordu Otogarı arka sokağındadır. Esnaflıkta yan komşusu olan paçası dardır şalvara benzer, körüklü çizmeyle beraber giyilir, Ingiliz kilodu da denen "kilot pantolon" ustası Bekir Usta'nin: 
“Herkes bana gelip körüklü çizme soruyor, sen neden yapmıyorsun?” diye sormasıyla körüklü çizme merakı başlamıştır.

Türkay Usta körüklü çizmeyi araştırmaya başlar ve 1960’l1 y1llarda bu yörede körüklü çizmenin alınıp satıldığını öğrenir. Ancak Ordu'da körüklü çizme yapan birini bulamaz. Ardından Samsun, Havza ve Bafra'yı dolaşır oralarda da körüklü çizmeci yoktur. Giresun'un Bulancak ilçesinde olduğunu duyar ve ustayı bulur. Ancak Bulancak’ta bulduğu usta mesleği ona öğretmeyi istemez, dükkânı tepelerde bir yerdedir, Türkay Usta'yı başından savar, oyalar. Nihayet bir gün dükkâna ulaşmayı başarmıştır ancak Bulancaklı Usta, Türkay Usta’yı dükkâna soktuğu gibi geri çıkarır, hemen 1şığı kapatır. Türkay Usta orada sadece kısa bir süre ve uzaktan bir körüklü çizme ve ahşap çizme kalıbı görür.
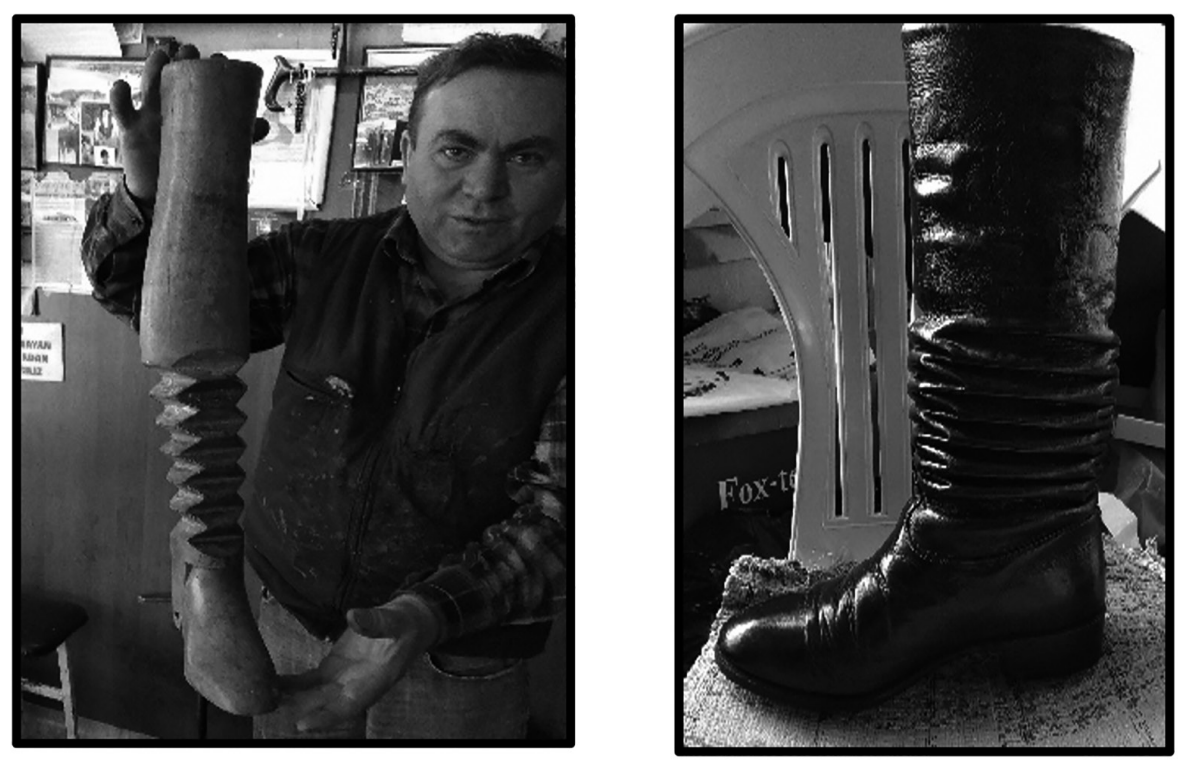

Foto 2. Körüklü çizmenin kamma adlı kalıbı Foto 3. Ustanın yaptığı ilk körüklü çizme.

Körüklü çizme aşkıyla yanıp tutuşan usta aramaya devam eder. Körüklü çizmenin Aydın Kuşadası'nda yapıldığını öğrenir ve oradan bir çizme getirtir. Çizmeyi inceler ve oraya gitmeye karar verir. 2003 yılında yola çıkar ilk durağı Kuşadası'dır. Körüklü çizme ustası Mehmet Karpuzcu'nun oğlu Mustafa Karpuzcu isimli bir us- 
tadan yardım alır. İlk körüklü çizmesini dokuz günde yapar. İlk yaptığı bu körüklü çizme ve "kamma kalıbı" denen bir çift kalıpla Ordu’ya dönmüştür.

Ordu'ya geldiğinde Yeni Mahalledeki kendi dükkânında körüklü çizme yapmaya başlar. Kuşadası'ndan getirdiği ilk kalıplar ve yaptığı ilk körüklü çizme dükkânda daima gözünün önünde durmaktadır. Usta körüklü çizme dışında Aceska adlı düz çizme ile bağcıklı ya da bağcıksız düz çizme gibi üç farklı çizme modeli siparişi almaktadır. Bunlar törensel kullanım için giyilmekte, ayrıca gündelik kadın-erkek çizmeleri ve ayakkabıları da sipariş üzerine üretmektedir.

Türkay Usta, 2015 yılında Gümrük ve Ticaret Bakanlığı tarafindan yılın ahisi seçilmiştir. 28. Ahilik Haftası kutlamalarında Ordu Valisi, Belediye Başkanı ve diğer yetkililerle beraber körüklü çizme giyerek şehir turu atmışlar, böylece yerel ve ulusal basına çıkmayı başarmışlardır. Bağkur emeklisi olan usta çizmeciliği severek yapmaktadır. Evli ve iki çocuk babasıdır (KK: 1). Mesleği ve esnaflığını geliştirmek için çok yer dolaşmış ve halen sosyal biri olarak gezmeyi seven bir kişiliktir. Onun sanatını geliştiren insanlarla kurduğu ilişkiler ve bunu geliştirme yeteneğidir. Bilmek için gezip görmek ve seyahate katlanmak, yeni yer ve kişiler tanımak, gördüklerinden ve yaşadıklarından tecrübeler kazanmak onun ustalık ruhuna büyük katkılar sağlamıştır. Turgay Yavaş'ın eşi ve çocuklarıyla kurduğu aile bağının çok güçlü olduğu görülmüş, onun sosyal ilişki becerisi kendisiyle yaptığımız görüşmelerdeki vurgularda yer bulmuştur. Bundan sonraki bölümler onun mesleğini oluşturan körüklü çizmenin yapılış ve işini icra ederken anlattığı meslek bilgilerinden oluşturulmuştur.

\section{2. Çizmenin Malzemesi ve Aletleri}

Körüklü çizmenin kökeninin Girit Adası olduğu usta tarafından dile getirilse de Eski Türk kültüründe çizme geleneğinin zaten var olduğu yukarıda belirtilmiştir. Ancak ayakkabıcılıkta ve körüklü çizme yapımında kullanılan araç gereçlerin, takımların bazılarının adının Yunanca olması (sahtiyan, freze, fort, falçata, piyanta...) her iki kültürün birbirinden etkilendiğini göstermektedir.

Bazı kaynaklarda körüklü çizmenin ilk olarak Batı Anadolu'da ortaya çıktığı, buraya da Sağır Usta olarak bilinen Hüseyin Rıfat Oral tarafindan Girit’ten Söke'ye göç esnasında getirildiği ve burada imalathanesinin açıldığı belirtilmektedir (Okca-Erun 2018: 233, 234). 


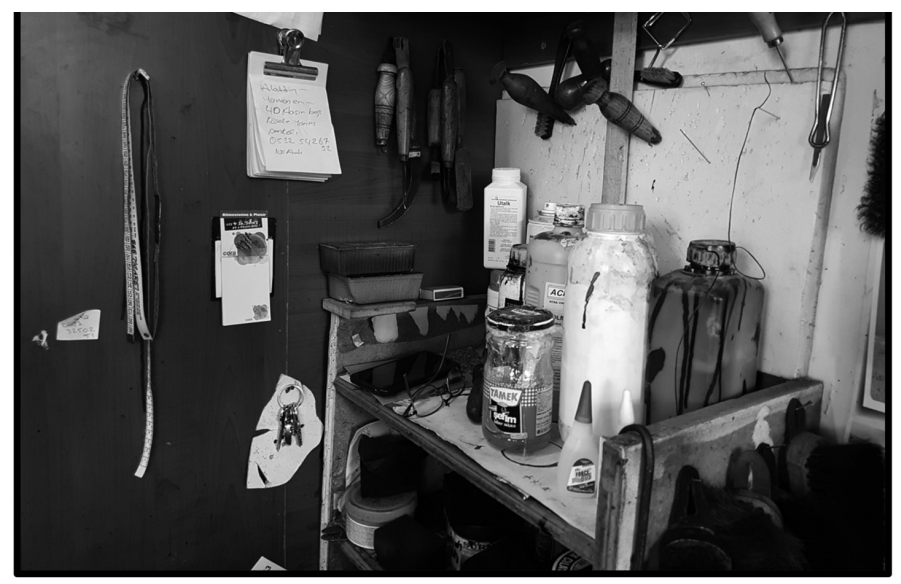

Foto 4. Mezüre, tığlar, çeşitli bıçaklar, çiriş, yapıştırıcılar, firçalar ve boyalar.

Ayakkabıcılıkta kullanılan ana maddelerden ilki gön adı verilen deridir. Körüklü çizmenin dış kısmı dana derisinden, iç kısmı sahtiyan ${ }^{1}$ denen keçi derisinden, tabanı kösele denilen sığır derisinden yapılmaktadır. Sahtiyan Ege Bölgesinden, kösele ve dana derisi İstanbul'dan getirtilir. Özenle yüzülen deri tuzlanarak kurutulduktan sonra ham deri halini alır, ardından şaplı su içinde belirli bir süre bekletilerek kıllardan arındırılır, buna tabaklama denir (Sümerkan 2008: 94). Tabaklanan deri kullanıma hazır hâle gelir. Bunların yanında çekiç, çiriş², falçata, kamma kalıbi ${ }^{3}$, freze (yuvarlak kesimler yapabilen makine) ve sökükçü adı verilen makine kullanılmaktadır. Ayrıca ıstampa (kalıp çıkarma), konç (çizmenin baldır kısmı), astar, fort (arka kısım, topuğun üstü), bombe (ayakkabının önü yâni burun kısmı), saya (çizmenin ayaküstü deri kısmı), yumurta topuk, düz topuk, kamara (ayakkabının yan tarafları), mastela (ayakkabıyı ıslatmak için kullanılan içi su dolu kova), monte çivisi, tahta çivi, gamma kalıbı, istaka (zımpara), payanda (alt tabana çakılan köselenin dışa çıkan kenarları), boya, perdah (köseledeki

\footnotetext{
1 Sahtiyan: Türklerde en yaygın olarak kullanılan ayakkabı "Sahtiyan"dır. Sahtiyan, kalın pençeli, ucu sivri ve ökçesizdir, genellikle keçi derisinden yapılmaktadır (Lecomte 1901:136). Günümüzde sahtiyan körüklü çizmenin iç kısmına dikilen keçi derisinin adı olmuștur. Parlak ve yumuşak bir deridir. İçinde gıcırtıyı sağlayan köpek boku bile olduğu usta tarafından dile getirilmektedir.

2 Çiriș: Konyada bir ağacın kökünde bulunan topraktan çıkarılmaktadır. Topraktan çıkarılan madde değirmende öğütülür un hâline getirilir. İçinde hiç katkı maddesi yoktur, sapsarı altın gibidir. Onu ayakkabı ustaları kendileri suda ekmek hamuru gibi karıştırır. Ondan sonra ayakkabının üst kısmına sürerler. Ayakkabı buradan hava alır, ayağı kokutmaz, ayakkabı deforme olmaz. Çiriş kalıbı tutar, bozmaz. Usta şu anda çiriş yerine ilaç denen bir maddenin kullanıldığını belirtmektedir.

3 Körüklü çizmenin kendine has kalıplarına "kamma kalıbı" adı verilir. Kamma kalıpları gürgen ağacından sağ ve sol ayak için ayrı ayrı olarak yapılmaktadır. Kalıba konacak derinin sslak ve nemli olması gerekir ve bir çizme kalıpta üç gün kalır.
} 
kenar düzeltme işlemi), akardiyon körük, boğma körük, baklava körük ve aceska (körüksüz ve boğazı aşağı kıvrık çizme) çizme yapımında kullanılan araç-gereç ve terimlerdendir (KK: 1).

\section{Körüklü Çizmenin Yapılışı}

Türkay Usta'nın da ustası olan Mustafa Karpuzcu'nun körüklü çizmenin yapılışı ile ilgili bir gazeteye verdiği röportaj Türkay Usta'nın dükkânının duvarında asılıdır. Burada yazan bilgilere ve ustanın kendi anlatımına göre körüklü çizmenin yapılışı şöyledir.

Kuşadası'nda ve Ordu'da yaptığı ilk örneklerin ardından kendine has bir yapım tekniği ve model geliştiren usta, bir çizmenin yaklaşık on beş günde yapıldığını anlatmaktadır. Çizme yapımının ilk aşaması ölçü alınmasıdır. Körüklü çizmede "pençe, kontüpiye, künye, baldır” olmak üzere dört farklı ölçü alınmaktadır. Bir sipariş defteri üzerine ölçüsü alınan ayağın kalıbı çizilerek, telefonu ve tahmini teslim tarihi kaydı not edilerek ölçüler alınmaktadır.

Ölçü alındıktan sonra kalıp çıkarılır buna "1stampa" denir. Kalıpla saya denen üst derisi kesilir. Ölçüye ve kalıba uygun olarak kesilen malzemelerde dikişler çizme ters çevrilerek iğneyle elde yapılmaktadır, bu yüzden körüklü çizmede el ve göz ustalığı çok önemlidir. Konç tarafının üstten $12 \mathrm{~cm}$ içerisine kösele koyup düzgün durması sağlanır. Ondan aşağısı yani körük olacak kısmın astarı sahtiyan denilen keçi derisinden kesilir. Sonra sıra saya dikimine gelir. Körüğe daha güzel şekil verebilmek için konçla astar birbirine çirişle yapıştırılır. Saya işleminden sonra müşterinin ayağına göre ayarlanmış kalıba köseleden taban astarı çakılır. Kösele sığır derisinin ilaçlı suda bekletilip sertleştirilmesiyle yapılmıştır. Fort ve bombe olarak tabir edilen ayakkabı kısmının arka ve burun kısmındaki sert olan bölgeler de kösele çirişle yapıştırılarak kullanılır. Kalıba çekme işleminde önce topuk tarafı kamara bölgesine kadar, sonra burun bölgesi kösele bombeyle beraber çekilir. Saya, taban astarına el dikişiyle çepeçevre dikilir.

Eğer çizmenin gıcırdaklı ${ }^{4}$ olması isteniyorsa bu aşamada kösele ile taban astarı arasına gaza batırılmış sahtiyan iki kat yapılarak konulur. Eskiden gıcırdak11 çizmelerin yürürken ses çıkarması bir gösteriş ve dikkat çekme vesilesi iken günümüzde pek rağbet görmemektedir. Gıcırdaklı çizme isteyen müşteriye latife 
yapılır, latifede bu işlemin kolay olmadığ 1 belirtilerek gıcırdak isteniyorsa bakkaldan 3-4 tane yumurta, bir miktar sucuk ve peynir alınması gerektiği belirtilir. Çoğu zaman müşteri buna inanır ve istenen malzemeleri getirir. Bu malzemelerle akşam eve gidildiğinde güzel ziyafetler çekilir.

Bir gece önceden mastela denilen kovada 1slatılıp yumuşatılmış köseleye iyice çiriş sürülüp monte çivisiyle tabana çakılır. Sonra etrafı falçatayla düzeltilip tahta çiviyle tutturulur.

Ökçe de tamamen köseleden yapılır çiriş ve tahta çiviyle sabitlenir. Etrafı falçata ile isteğe göre yumurta topuk veya düz olacak şekilde kesilir. Birbirine dikilen ve "çiriş" yardımıyla yapıştırılan malzemeler ıslatılıp nemlendirilerek üç gün gürgen ağacından yapılan ve "gamma" denilen kalıplara konulur. Kalıba koyma 2 - 3 kez aşamalı olarak yapılır. Alt kösele sarımsak kokusu çıkana kadar "istaka" denilen aletle sürtülerek parlatılır. Topuk ve köselenin "piyanta" denilen kenar kısımları zımpara ile temizlenerek parlatılır, boya ve perdahı yapılır. Kalıptan çıkarılıp, içeriden çıkan tahta çiviler özel bir âletle kırılır. Müşterinin isteğine göre akordiyon, boğma veya baklava denilen körükler kalıpta kırılıp cila sürülerek ispirto ile yakılan ateşte ütülenir. Böylece körükler de hazır olur.

Körüksüz olarak üretilen çizmelere “aceska” denmektedir. Bu tür çizmeler hava almadığından hem giyerken zorlanılmakta hem de ayağı terletebilmektedir. Aceskayı giymek zor olduğundan “Aceska giyen terler.” diye bir söz de kullanılmaktadır. Osmanlı döneminde subaylar ve Giresunlu Miralay Osman Ağa bu çizmeden giymiştir.

Körüklü çizmede körüklerin amacı hem giyen kişiye bir hava katmak, hem de ayakkabının hava almasını sağlamaktır. Körüklü çizmede üç veya yedi körük bulunmakta ve bu çizmelere baklava veya akordiyon körüklü çizme de denmektedir $(\mathrm{KK}: 1)$.

\section{4. Çizmenin Kullanış Anları ve Anlamları}

Körüklü çizme Ege Bölgesinde deve güreşi şenliklerinde deve sahipleri ve güreş izleyicileri tarafından geleneksel olarak giyilmektedir (Gülmez 2018: 153).

Ordu yöresinde at yetiştiricileri ve ata binenler tarafından kullanılan körük- 
lü çizmeler, günümüzde çoğunlukla yayla şenliklerinde yöresel kıyafetlerle birlikte giyilmektedir. Gündelik olmayan kutlu ve törensel zamanlarda varlık sahibi oluşun göstergesi olan bir kıyafetin bütünleyici parçasıdır.

Osmanlı ordu subaylarının batılı asker üniformasının bir parçası olan çizmeleri örnek aldıkları ve o çizmelerin en gösterişlisi olan körüklü çizmeler bir dönem askerler ve özellikle rütbeli subaylar tarafından da kullanılmıştır. Daha sonra sivil halk üzerinde erlik, yiğitlik ve ağalık sembolü olmuş ve yaygınlık kazanmıştır. Burada Mustafa Kemal Paşanın özel muhafızlığını yapan gönüllü Giresun Uşaklarının ayaklarında Aceska ve hatta bazen körüklü çizmeler görülmesi bu etkileşimin örneğidir. Çizmelerin adeta askeri bir sembol olarak taşınması Aydın, Uşak, Kütahya ve Giresunlu milislerin o dönedeki kıyafetleri yansıtmıştır. Kurtuluş Savaşı sırasında iki gönüllü alaylar oluşturan ve Milis Yarbay Osman Ağa ile yapılan 19.02.1922 tarihli Vakit Gazetesi ${ }^{5}$ röportajına alınan milisler ile Ağanın kıyafetlerine yansımıştır (Menteşeoğlu 2014: 372).

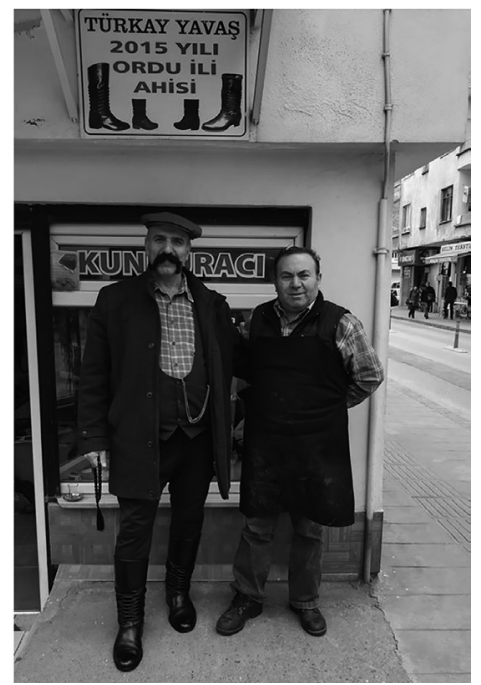

Foto 5. Turgay Yavaş Ustanın iş yeri ve çizme müşterisi Hasan Öztaş (Kendi arşivi, 2019). 
Eskiden ağa denilen yeri yurdu çok olan zengin kişiler için körüklü çizme bir asalet sembolüydü. Çarşıya pazara onunla giderler, ata onunla binerlerdi. G1cırdaklı çizme ise çarşıda pazarda ağaya ayrı bir hava katardı.

Günümüzde özellikle ahilik haftasındaki şenliklerde bölgenin ileri gelenleri vali, belediye başkanı, esnaf odaları başkanı vs. "sekiz köşeli kasket" ve "İngiliz kilot pantolonu” ile beraber Körüklü Çizme’yi bir aksesuar olarak giymekte ve halkın arasında dolaşmaktadırlar.

Hıdırellez Şenlikleri'nde ve Mayıs Yedisi Kutlamaları'nda Gürgentepe ve Gölköy ilçelerindeki güreşlerde güreş ağalığı için mücadele edenler körüklü çizme giymektedirler. Ayrıca yine bu şenliklerde düzenlenen at yarışlarında ata binenler ve at sahipleri körüklü çizmeleriyle boy göstermektedirler. Ordu ilinin yaylalarında düzenlenen yayla şenliklerine de varlıklı kişiler körüklü çizmeyle katılmaktadırlar. Körüklü çizmeyle beraber giyilen kasketli kıyafetler, bu bağlamda şenliğe maddi katkı veren ağalık sembolü olarak görülmeye başlanmıştır.

İl dışından körüklü çizme siparişleri gelmektedir. Ustanın anlattığına göre Sivas'tan yetkili birisi ustayı arar ve ona bir resim göndereceğini belirterek resimdeki çizmeden yapmasını ister. Bu resim Atatürk’ün giydiği çizmedir. Usta aynı çizmeden yapar ve siparişi ona gönderir. Milli Mücadele Döneminde Atatürk'ün, paşaların, rütbeli askerlerin yanı sıra sivil güçlerden Egeli milis Efeler ile milis Giresun Uşaklarının görsel arşivlerdeki görüntülerinde çizmeler üniformanın vazgeçilmez parçası olarak görülmektedir. Asker ile sivillerin kurtuluş mücadelesi yıllarındaki birlikteliği er ve erkek kıyafetinin bir sembolü olarak hem çizme hem de ceket pantolon şeklinde bir etkileşimi doğurmuştur. Bu etkileşim Erzurumlu Kara Fatma (Fatma Seher Erden, Erzurum 1888-İstanbul 1955) gibi kadınların bile çizme giyip erkek subayların kıyafetini tercih ettikleri birçok görselde kayıtlidir (Uyanıker 2009: 56, Belge 24 ile Foto 31).

Başka bir hikâye ise oldukça acıklıdır. Amansız hastalığa yakalanmış bir kız, babasına ölmeden evvel bir hediye bırakmak istiyormuş. Bir gün İstanbul'dan ustayı aramış: "Babama bir körüklü çizme yapar mısın?” demiş; durumunu anlatmış. Usta buna çok üzülmüş, hemen körüklü çizmeyi yapıp göndermiştir. 
Halk oyunları için bay ve bayanlara özel çizmeler de yaptığını belirten usta, yurdun çeşitli yerlerinden ve hatta yurt dışından bile sipariş aldığını anlatmaktadır. Boş vakitlerinde minyatür biçimli körüklü çizmeleri kalemlik olarak dizayn ederek, hediyelik olarak satışa sunmaktadır.

\section{Körüklü Çizmenin Gelenekle İlişkisi ve Güncel Sorunlar}

Genel anlamda baktığımızda ayakkabının birçok kültürde önemli bir yeri vardır. Günümüzde hâlâ devam eden bir gelenek olarak evlenmek isteyen oğulun, babasının ayakkabısını yere veya kapının eşiğine çivilemesi bunlardan bir tanesidir. Ayakkabı ile ilgili bir diğer gelenek ise gelinin, arkadaşlarının adını, gelinlik ayakkabısının altına yazmasıdır. Buna göre ayakkabıdan adı silinenin yakında evleneceğine inanılır (Yolcu 2014: 20). Körüklü çizme giyimi ve yapımı da Ordu'da kendine has bir gelenek olarak devam etmektedir. Bu geleneğin devam etmesinde en önemli etken yukarıda bahsettiğimiz Türkay Usta'dır.

Körüklü çizme geleneğinin Ordu'da bir zamanlar var olduğunu öğrenen ayakkabı sevdalısı bir ustanın geleneği yaşatmak için yaptığı mücadeleler anlatılmaya değerdedir. Karadeniz Bölgesinde bu mesleği yapanların araştırılması ve bulunamaması ardından Kuşadası'na yapılan uzun ve yorucu bir yolculuk, orada mesleği öğrenmek için verilen çabalar bugün Ordu'da körüklü çizme giyme ve yapma geleneğinin yaşatılmasına vesile olmuştur. Bu açıdan bakıldığında Türkay Usta kaybolmaya yüz tutmuş bir geleneği gün yüzüne çıkarmayı başarmıştır.

"Gençlere sanat muhakkak lazım olur, öğrenilmesi lazım. Zanaatkârın hanımı öğleye kadar açtır, öğleden sonra ise toktur. Eski paşalar bile kızlarını zanaatkâra verirmiş. Ölene kadar sanat seninle gider, kaybolmaz” diyen Türkay Usta mesleğine verdiği kıymeti bu sözlerle dile getirmektedir.

Körüklü çizmeyi gıcırdaklı yaptırmak isteyenin de parasıyla ziyafet çektirmek gelenek hâline gelmiştir. Gıcırdaklı olmasını istiyorum diyen müşteri zaten varlıklıdır, yörenin ileri gelenlerindendir. Müşteri:

- “Gıcırdaklı olması için ne gerekli?” diye sorduğunda.

- “1 kilo sucuk, 1 koli yumurta, bir şişe rakı gerekli.” gibi cevaplar verilir. Akşama da usta ve dükkânda bulunanlar bu malzemeyle ziyafet çekerler (KK:1). 
“Hamama giren terler” atasözü, körüklü çizmeciler arasında "aceska giyen terler" şekline dönüşmüştür. Aceska yukarıda da belirttiğimiz gibi körüksüz çizmedir. Giymesi ve çıkarması oldukça güçtür. "Aceska giyen terler” diyerek hem bir gerçeği dile getirmişler hem de çizme taşımanın, çizmeyle gezmenin her babayiğgidin harcı olmadığını belli bir varlık gerektirdiğini belirtmişlerdir. Çizme giyen kişi yörenin ağasıdır, malı mülkü yerindedir. Yanına gelenleri ağırlar, bulunduğu ortamda kimseye hesap ödetmez.

Ordu'da körüklü çizmenin yayla şenliklerinde, Mayıs Yedisi, Hıdırellez gibi mahallî ve mevsimsel törenlerde, at yarışlarında, düğünlerde tekrar giyilmesi yeniden canlandırılan geleneğe örnek verilebilir. Ulubeyli bir at meraklısı, gittiği her yere atıyla giden, çarşıda pazarda atla dolaşan (müteveffa) Sarı Mustafa'nın ayağındaki gıcırdaklı körüklü çizmesini görmeyen yoktur. Ayrıca yaylacılık yapan yörede ağa olarak nam salmış (müteveffa) Reşit Ağa, Fehmi Ağa gibi kişilerin de çoğu zaman günlük hayatta bile körüklü çizmeleriyle gezdikleri bilinmektedir (KK.2).

Yine günümüzde, mesleğin tanıtımını yapmak için vali, kaymakam ve belediye başkanları; tüccarlar, esnaflar ve yöre halkı körüklü çizmeye rağbet göstermektedir. Ayrıca körüklü çizmenin babadan oğula ve toruna kalacak önemli bir hatıra niteliği taşıdığı inancı da hâkimdir. Yukarıda bahsettiğimiz hasta bir kızın babasına hatıra olarak körüklü çizme bırakması, onun kendi başına bir varsıl erkek kültü olarak algılandığına kişisel bir anlatıdır. Çizmenin pantolon, yelek, beyaz gömlek, ceket ve köşeli kasketle beraber oluşturduğu törensel giyinme formu erkek subayların üniformalarını, günümüz erkek modasında yeniden yorumlamıștır.

Çizmeciliğin meslekî sorunları sanayileşen sektöre karşı direnemeyen ayakkabıcılarla benzerdir. Hazır giyim ayakkabılarla birlikte diğer birçok meslekte olduğu gibi el sanatına bağlı üretimler ve bu esnaflar kaybolmaya yüz tutmuştur. Maliyeti düşük ve kalitesiz malzemelerin piyasaya sürülmesi ayakkabıcılarla birlikte mesleğin devamlılığını, yukarıda anlatıldı̆̆g gibi, sekteye uğratmıştır. Körüklü çizmeci olarak orduda tek olan Yavaş Kundura, çırak bulamadığını derinin pahalı olduğunu belirtmektedir. Köyden kente göç ve at yetiştirme geleneğinin azalması da körüklü çizme siparişlerini azaltmıştır. Gündelik hayatta kullanılmayan bir nesne olan körüklü çizmeye olan talep Doğu ve Orta Karadeniz'de tek 
usta ile yaşayabilmektedir. Ustanın değerlendirmesine göre işin yapım aşamasının oldukça zor ve gelirinin de az oluşu yüzünden mesleğe çırak bulma ve yetiştirmede güçlükler birikim ve becerinin aktarımını aksatacaktır.

\section{Sonuç}

Milletlerin, tarih sahnelerinde görünmelerinden bu yana, topluluk üyeleri arasında birlik ve beraberliği sağlayan, ortak değerlere gelenek adı verilir. Meslekler geleneğin bir parçasıdır. Bütün geleneksel meslekler o milletin hafızasını oluşturan unsurlar taşır. Bu mesleklerden biri de körüklü çizmeciliği de kapsayan ayakkabiciliktır.

Osmanlı döneminin sonlarında ve Cumhuriyetin döneminin ilk yıllarında Ordu ve yöresinde körüklü çizme geleneğinin var olduğunu daha sonraları ise yok olmaya yüz tuttuğunu görmekteyiz. Meraklı ve sanatına âşık bir ustanın bu sanatı tekrar yaşatabilmek için girdiği mücadeleler ve bu mücadelelerin sonucunda hedefine ulaşması, körüklü çizmeyi tekrar yöre halkına sevdirmesi övülmeye değer bir hikayedir.

Günümüzde geleneksel bayram ve törenlerde giyilen körüklü çizmeler ustanın deyimiyle "babadan oğula, dededen toruna kalacak mirastır". Yapım aşamas1 oldukça emek istediğinden çırak bulma ve yetiştirme oldukça zordur. Mesleğin yok olmaması için Ordu ve yakın çevrede tek olan Türkay Usta'nın desteklenmesi, meslekî eğitimlerde değerlendirilmesi, geleneksel ürün satış yerlerinde yer almasının sağlanması gerekmektedir. Ordu'da geleneksel ayakkabıcılık desteklemelidir. Belediye, şehrin geleneksel ürünlerini, kaybolmaya yüz tutmuş geleneksel meslek ustalarını "geleneksel çarşıda" toplamalıdır. 


\section{Kaynakça}

Baykara, Tuncer (2001), Türk Kültür Tarihine Bakışlar. Ankara: AKMB Yayınları.

Çoruhlu, Yaşar (2003), Orta ve İç Asya' da Kazı ve Araştırmalarda Elde Edilen Materyale Göre Erken Devir Türklerinde Çizme, Ayakkabı Kitabı. Haz. Emine Gürsoy Naskali. İstanbul: Kitabevi Yayınları.

Diyarbakırlığlu, M. Ali (2010), Kaybolan Meslekler ve Son Ustalar. İstanbul: İTO Yayınları.

Ekici, Metin (2007), Halk Bilgisi (Folklor) Derleme ve İnceleme Yöntemleri. Ankara: Geleneksel Yayınları.

Ergin, Muharrem (1958), Dede Korkut Kitabı, Ankara: TDK Yayını.

Ergin, Muharrem (1970), Oğuz Kağan Destan 1000 Temel Eser, İstanbul: MEB Yayını.

Esnaf ve Sanatkârlar Özelinde Sektör Analizleri Projesi Deri, Giyim ve Ayakkabı Sektörü (2017), Komisyon, Ankara: T.C. Gümrük ve Ticaret Bakanlığı Yay.

Genç, Reşat (1997), Kaşgarlı Mahmud'a Göre XI. Yüzyılda Türk Dünyası. Ankara: TKAE Yayınları.

Gülmez, Nurettin (2018), "Gıcırdaklı Çizme Ustası İbrahim Ethem Karakaş”. II. Uluslararası Selçuk-Efes Devecilik Kültürü ve Deve Güreşleri Sempozyumu 18-20 Ocak 2018. Selçuk-İzmir. 1. Cilt, s. 152-169.

Kafesoğlu, İbrahim (2016), Türk Millî Kültürü. İstanbul: Ötüken Yayın1.

Kaşgarlı Mahmud (2005), Divânü Lugati t-Türk, İstanbul: Kabalcı Yayınevi.

Kuzgun, Yıldız (2003), Meslek Rehberliği ve Danışmanlığına Giriş, Ankara: Nobel Yayın Dağılım.

Lecomte, Pretextat (1901), Türkiye'de Sanatlar ve Zeneatlar 19.yy. Sonu. Haz. Ayda Düz. İstanbul: Tercüman Yay.

Menteşeoğlu, Ö. Erden (2014), Mustafa Kemal Paşanın Muhafız Alay Komutanı Milis Yarbay Osman Ağa, Ankara: Kişisel yayın.

Örnek, S. Veyis (1995), Türk Halkbilimi, Ankara: KB Yayını.

Sümerkan, Mustafa Reşat (2008), Trabzon Yöresi Geleneksel El Sanatları. Trabzon: Serander Yayını.

Şen, Mesut (2003), Ayakkabı İle Illgili Kelimeler Üstüne Ayakkabı Kitabı, Hzl. Emine Gürsoy Naskali. İstanbul: Kitabevi Yayınları.

Uyanıker, Ferhat (2009), Millî Mücadele'de Türk Kadını, Ankara: Genelkurmay Askerî Tarih ve Stratejik Etüt Başkanlığı Yayınları.

Yıldırım, Dursun (1998), Türk Bitiği. Ankara: Akçağ Yayınları.

Yolcu, Mehmet Ali (2014), Nevşehir Yöresinde Yaşayan Geleneksel Meslekler. Ankara: Nevşe- 
hir Hacı Bektaş Veli Üniversitesi Yayınları.

\section{Kaynak Kişi}

KK:1. Türkay Yavaş, 1962 Doğumlu, Ordu Ulubey Uzunmahmut Köyü, İlkokul Mezunu, Körüklü Çizme Ustası, Ordu Merkezde Yaşıyor.

KK:2. Ayşe Eren, 1950 Doğumlu, Ordu Ulubey Çubuklu Köyü, Okuma Yazması Yok, Ev Hanımı. 